\title{
Hubungan Antara Asupan Energi, Zat Gizi Makro dan Total Energy Expenditure dengan Status Gizi Anak Sekolah Dasar
}

\section{Correlation between Energy Intake, Macro Nutrients and Total Energy Expenditure and Nutritional Status of Elementary Students}

\author{
Baiq Qamariyah* ${ }^{1}$, Triska Susila Nindya ${ }^{1}$
}

\begin{abstract}
ABSTRAK
Latar Belakang: Status gizi pada anak sekolah dapat dipengaruhi banyak faktor diantaranya asupan energi, asupan zat gizi makro dan total energy expenditure.

Tujuan: penelitian ini adalah mempelajari hubungan antara asupan energi, zat gizi makro dan total energy expenditure dengan status gizi anak sekolah dasar.

Metode: Penelitian adalah observasional analitik dengan rancang studi cross-sectional yang dilaksanakan di SDN Pacarkembang 1 Surabaya pada Juli 2017. Sampel Penelitian adalah siswa kelas 4 dan 5 sebanyak 66 orang yang diambil dengan simple random sampling. Variabel penelitian meliputi status gizi, asupan energi, asupan zat gizi makro dan total energy expenditure. Pengumpulan data menggunakan metode wawancara dengan recall $2 \times 24$ jam, recall aktivitas fisik, pengukuran berat badan dan tinggi badan. Analisis data menggunakan uji independent sampel $T$-test.

Hasil: penelitian menunjukkan bahwa sebagian besar status gizi siswa normal (69,7\%). Terdapat hubungan signifikan antara asupan energi $(p=0,000)$, protein $(0,017)$, lemak $(p=0,040)$, karbohidrat $(p=0,001)$ dan total energy expenditure $(p=0,000)$ dengan status gizi anak sekolah dasar.

Kesimpulan: asupan energi, zat gizi makro dan total energy expenditure berhubungan dengan status gizi anak sekolah dasar. Sebaiknya anak sekolah dasar dapat mengurangi konsumsi makanan tinggi energi protein dan lemak serta meningkatkan aktivitas fisik.
\end{abstract}

Kata kunci: asupan energi, zat gizi makro, total energy expenditure, status gizi 


\section{ABSTRACT}

Background: Nutritional status of students can be influenced by many factors such as energy intake, macro nutrients intake and total energy expenditure.

Objectives: this study aimed to determine association of energy intake, macro nutrients intake and total energy expenditure with nutritional status of elementary students.

Methods: this study was observasional analitic research with cross-sectional design wich was done in SDN Pacarkembang 1 Surabaya on July 2017.The sample was 66 students in grade 4 and 5 with simple random sampling. Variabel in study was nutritional status, energy intake, macro nutrient intake, and total energy expenditure. Data were collected through interview using food recall $2 \times 24$ hour, physical activity recall, weight and high measurement. Analysis data used independent sample T-test analysis.

Results: this study showed the most of nutritional status was normal (69.7\%). There were correlations of energy intake $(p=0.000)$, protein $(p=0.017)$, fat $(p=0.040)$ carbohydrate $(p=0.001)$ and total energy expenditure $(p=0.000)$ with nutritional status of elementary students.

Conclusion: energy intake, macro nutrient intake and total energy expenditure were associated with nutritional status of school children.School children should reduce the consumption of food high in energy, protein, fat and increase physical activity.

Keywords: energy intake, macro nutrients, total energy expenditure, nutritional status

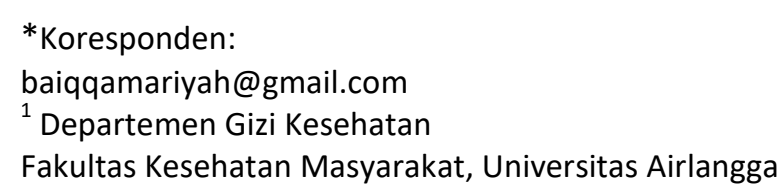

\section{PENDAHULUAN}

Status gizi merupakan indikator yang dapat menggambarkan kondisi kesehatan dipengaruhi oleh asupan serta pemanfaatan zat gizi di dalam tubuh ${ }^{1}$. Asupan energi yang masuk ke dalam tubuh diperoleh dari makanan yang dikonsumsi sedangkan pengeluaraan energi digunakan untuk metabolisme basal, aktivitas fisik dan efek termik makanan. Keseimbangan antara pemasukan energi dan pengeluarannya akan menciptakan status gizi normal. Namun bila keadaan tersebut tidak terjadi maka dapat menimbulkan masalah gizi baik masalah gizi kurang dan masalah gizi lebih. Anak sekolah dasar adalah salah satu kelompok usia yang rawan terhadap masalah gizi.

Global Nutrition Report menunjukan jumlah anak status gizi overweight dibawah 5 tahun mengalami peningkatan ${ }^{2}$. Diketahui anak status gizi overweight di ASIA tahun 2005 sebesar 15 juta, tahun 2010 sebesar 17 juta dan meningkat menjadi 20 juta pada tahun $2014^{2}$. Tren prevalensi gizi lebih anak 6-12 tahun Indonesia menunjukkan peningkatan. Diketahui prevalensi gizi lebih anak 6-12 tahun berdasarkan Riskesdas tahun 2010 sebesar 9,2\% dan 2013 sebesar $18,8 \%^{3}$. Propinsi Jawa Timur termasuk dalam katagori propinsi di Indonesia dengan prevalensi anak gemuk diatas prevalensi Indonesia. Diketahui prevalensi anak gemuk Jawa Timur adalah $22,2 \%{ }^{4}$.

Surabaya adalah ibu kota propinsi Jawa Timur dengan tingkat UMK (Upah Minimum Kabupaten/Kota) tertinggi ${ }^{5}$. Keadaan ini memicu peningkatan taraf hidup masyarakat Surabaya. Peningkatan taraf hidup diikuti dengan peningkatan daya beli termasuk pada daya beli terhadap makanan. Keadaan tersebut berdampak terhadap peningkatan jumlah penjual makanan ${ }^{6}$. Namun pada faktanya peningkatan jumlah penjual 
makanan tidak diimbangi dengan peningkatan nilai gizi makanan yang dijual. Pada umumnya makanan yang disediakan adalah makanan padat energi dan makanan siap saji. Berdasarkan hasil observasi di lingkungan SDN Pacarkembang 1 Surabaya terdapat banyak penjual makanan di luar lingkungan sekolah. Makanan - makanan yang dijual terdiri dari jenis makanan manis, asin dan makanan yang digoreng. Selain itu juga terdapat penjual makanan di dalam lingkungan sekolah dengan jenis makanan yang dijual adalah sama.

Ketidakseimbangan energi di dalam tubuh dapat menyebabkan perubahan berat badan $^{7}$. Kondisi keseimbangan positif terjadi apabila energi yang masuk lebih besar dibandingkan dengan pengeluarannya. Di dalam tubuh konsumsi energi berlebih akan dirubah dalam bentuk simpanan lemak pada jaringan adiposa ${ }^{8}$.

Total energy expenditure (TEE) diartikan sebagai pengeluaran energi total individu yang berasal dari tiga komponen yaitu metabolisme basal, efek konsumsi makanan dan aktivitas fisik $^{1}$. Metabolisme basal adalah penggunaan energi pada saat istirahat.Metabolisme basal menyumbang 10 - 20\% terhadap pengeluaran energy tubuh ${ }^{1}$. TEE juga dipengaruhi oleh efek termik makanan.Efek termik makanan didefinisikan sebagai energi panas yang dihasilkan dalam proses pencernaan makanan ${ }^{1}$. Komponen pengeluaran energi terbesar digunakan untuk aktivitas fisik ${ }^{9}$.

Permasalahan gizi lebih pada usia sekolah dapat berlanjut hingga dewasa dan meningkatkan risiko penyakit degenartif seperti hipertensi, diabetes mellitus, dan jantung koroner. Masalah gizi lebih merupakan masalah kompleks yang diakibatkan karena faktor hereditas, pilihan makan, asupan energi, aktivitas fisik, serta pengaruh lingkungan. Penelitian Vertikal menjelaskan bahwa asupan energi berlebih pada siswa sekolah dasar meningkatkan risiko terjdinya gizi lebih. Diketahui bahwa siswa dengan rata - rata asupan energi tinggi berisiko 3 kali lebih tinggi untuk mengalami gizi lebih ${ }^{10}$. Persamaan pendapat juga dikemukakan pada penelitian Kharismawati dan Sunarto (2010) bahwa konsumsi energi pada anak obesitas lebih tinggi dibandingkan dengan anak tidak obesitas. Selisih asupan energi antara anak obesitas dengan anak tidak obesitas mencapai $112 \mathrm{kkal}^{11}$. Faktor lain yang berpengaruh terhadap kejadian gizi lebih pada usia sekolah adalah aktivitas fisik. Penurunan tingkat aktivitas fisik pada anak sekolah beriringan dengan peningkatan lingkungan ke arah yang lebih modern. Contoh penurunan tingkat aktivitas fisik ini dapat dilihat dari beberapa kegiatan yang biasa dilakukan anak sekolah seperti mengganti kebiasaan berjalan kaki atau bersepeda ke sekolah dengan mengendarai mobil atau diantar, dan kebiasaan bermain di luar rumah bersama teman dengan aktivitas di depan layar. Berdasarkan hasil penelitian Hutahean (2013) penurunan aktivitas fisik menjadi faktor dominan terhadap kejadian gizi lebih pada siswa sekolah dasar ${ }^{12}$. Berdasarkan penjelasan diatas maka penting untuk melakukan penelitian terkait dengan hubungan asupan energy, zat gizi makro dan total energy expenditure dengan status gizi anak sekolah dasar.

\section{METODE}

Penelitian ini adalah penelitian observasional analitik dengan rancang studi cross-sectional yang dilaksanakan pada Juli 2017 di SDN Pacarkembang 1 Surabaya. Populasi penelitian adalah siswa sekolah dasar di SDN Pacarkembang 1 Surabaya berjumlah 931 orang. Besar sampel penelitian dihitung menggunakan rumus Lameshouw dan Lwanga diperoleh dengan jumlah popualsi 931 siswa dan diperoleh sampel sebesar 66 siswa yang diambil menggunakan metode simple random sampling. Variabel penelitian meliputi status gizi, asupan energi, asupan protein, asupan lemak, asupan karbohidrat dan total energy expenditure.

Teknik pengumpulan data dilakukan dengan wawancara menggunakan recall $2 \times 24$ jam, selanjutnya dianalisis menggunakan nutrisurvey dan dikatagorikan menjadi kurang (rata-rata asupan $<77 \%$ AKG), cukup (ratarata asupan $77 \%$ AKG) dan lebih (rata-rata asupan $>77 \%$ AKG). Data TEE diperoleh menggunakan teknik wawancara recall aktivitas fisik selama $1 \times 24$ jam dan dihitung 
dengan mengalikan angka metabolisme basal (BMR) dengan tingkat aktivitas fisik (PAL). Status gizi diperoleh melalui penilaian antropometri. Pengukuran berat badan menggunakan timbangan digital dengan ketelitian 0,1 kg. Tinggi badan diukur menggunakan microtoise dengan ketelitian 0,1 $\mathrm{cm}$. Status gizi dinilai menggunakan indikator Z-scoreyaitu obese ( $>3 \mathrm{SD}$ ), overweight ( $>2$ $\mathrm{s} / \mathrm{d} 3 \mathrm{SD}$ ), risiko overweight ( $>1 \mathrm{~s} / \mathrm{d} 2 \mathrm{SD})$, normal(-2 s/d 1 SD), kurus $(-3 \mathrm{~s} / \mathrm{d}<-2 \mathrm{SD})$ dan sangat kurus $(<-2 \mathrm{SD})$. Selanjutnya status gizi diklasifikasikan menjadi 2 kartagori yaitu obese (Z-score $>1 \mathrm{~s} / \mathrm{d}>3 \mathrm{SD}$ ) dan normal ( $Z$ score $-2 \mathrm{~s} / \mathrm{d} \quad<-3 \mathrm{SD})$. Analisis data menggunakan uji independent sample T-test.

\section{HASIL DAN PEMBAHASAN}

Hasil penelitian menunjukkan bahwa responden penelitian terdiri atas 30 siswa laki - laki dan 36 siswa perempuan. Rata - rata usia siswa adalah $10 \pm 0,714$ tahun. Rata - rata berat badan siswa adalah $34,22 \mathrm{~kg}$ dan tinggi badan adalah 136,6 cm. Status gizi siswa digolongkan menjadi obese dan normal. Hasil penelitian menunjukkan bahwa terdapat 20 $(30,3 \%)$ siswa status gizi obese dan $46(69,7 \%)$ siswa status gizi normal.

Berdasarkan hasil penelitian diketahui bahwa rata - rata asupan energi pada siswa status gizi obese dalah 1917,64 kkal dan siswa status gizi normal adalah 1600,13 kkal. Hasil analisi uji statistik menunjukkan bahwa asupan energi berhubungan signifikan dengan status gizi anak sekolah dasar $(p=0,000)$. Hasil penelitian sejalan dengan penelitian Rokhmah (2016) yang menyatakan bahwa asupan energi berhubungan dengan status gizi siswi di Pondok Pesantren Al-Izzah Kota Batu ${ }^{13}$. Hasil penelitian juga didukung oleh penelitian Vertikal (2012) yang menyatakan bahwa asupan energi lebih besar pada siswa status gizi lebih dibandingkan siswa status gizi normal ${ }^{10}$

$$
\text { Penelitian Kurdanti }
$$

mengemukakan hal yang sama yaitu asupan energi pada remaja usia 10 -18 tahun lebih tinggi pada status gizi obese dibandingkan dengan status gizi tidak obese ${ }^{14}$. Pada hasil penelitian ini diketahui bahwa obese dan normal memiliki selisih rata- rata asupan energi sebesar 317,51 kkal. Sejalan dengan hasil penelitian ini, penelitian di Cina menyebutkan bahwa konsumsi energi lebih tinggi pada anak dengan status gizi obesitas dibandingkan dengan anak yang tidak obesitas $^{15}$.

Tabel 1.Karakteristik Siswa Sekolah dasar SDN Pacarkembang 1 Surabaya

\begin{tabular}{lll}
\hline Karakteristik Siswa & $\mathbf{n}$ & $\%$ \\
\hline Jenis Kelamin & & \\
Laki - laki & 30 & 45,5 \\
$\begin{array}{l}\text { Perempuan } \\
\text { Kelas }\end{array}$ & 36 & 54,5 \\
4 & & \\
5 & 34 & 51,5 \\
Umur (tahun) & 32 & 48,5 \\
9 & & \\
10 & 25 & 37,8 \\
11 & 36 & 54,5 \\
Status Gizi & 5 & 7,7 \\
Obese & & \\
Normal & 20 & 30,3 \\
\hline
\end{tabular}

Energi berasal dari konsumsi makanan mengandung karbohidrat, protein, dan lemak. Karbohidrat, protein dan lemak tergolong dalam katagori zat gizi makro yang berperan sebagai sumber energi di dalam tubuh ${ }^{16}$. Diketahui bahwa $1 \mathrm{~g}$ bahan makanan mengandung karbohidrat dan protein menyumbangkan energi sebanyak 4 kkal sedangkan pada $1 \mathrm{~g}$ bahan makanan mengandung lemak menyumbangkan 9 kkal energi ${ }^{17}$. Konsumsi makanan mengandung zat gizi makro berlebih dapat menyebabkan peningkatan simpanan energi di dalam tubuh. Kondisi tersebut jika terjadi secara terus menerus dapat mengakibatkan kenaikan berat badan dan menyebabkan obesitas ${ }^{8}$.

Rata - rata asupan zat gizi makro pada siswa status gizi obese lebih tinggi dibandingkan dengan siswa status gizi normal. Diketahui bahwa siswa status gizi obese memiliki rata - rata asupan protein sebanyak $74,17 \mathrm{~g}$, lemak 72,13 g dan karbohidrat 243,73 g. Sedangkan pada siswa status gizi normal rata - rata asupan adalah protein $61,60 \mathrm{~g}$, lemak 60,59 g dan karbohidrat 201,84 g. Berdasarkan hasil analisis statistik terdapat 
hubungan signifikan antara asupan protein $(p=0,017)$, lemak $(0,040)$ dan karbohidrat $(p=0,001)$ dengan status gizi anak sekolah dasar. Hasil penelitian sejalan dengan penelitian Sultana et al, 2015 menyatakan bahwa rata - rata asupan karbohidrat dan protein lebih tinggi pada anak status gizi gemuk dibandingkan dengan anak status gizi normal dan kurus ${ }^{18}$. Hasil penelitian juga didukung dengan hasil penelitian di Manado yang menyatakan bahwa asupan protein dan lemak berhubungan dengan status gizi ${ }^{19}$ dan juga penelitian yang dilakukan pada 17 ribu remaja di Indonesia yang menunjukkan bahwa asupan protein memiliki hubungan terhadap kejadian gizi lebih ${ }^{20}$.

Karbohidrat adalah salah satu zat gizi makro yang menjadi sumber energi di dalam tubuh. Konsumsi karbohidrat yang tidak seimbang berdampak terhadap simpanannya di dalam tubuh. Bentuk simpanan karbohidrat di dalam tubuh adalah glikogen ${ }^{21}$. Fungsi glikogen sebagai bentuk simpanan karbohidrat tubuh hanya terbatas untuk keperluan otot dan tidak dapat dikembalikan dalam bentuk glukosa dalam darah ${ }^{21,8}$. Asupan karbohidrat yang melebihi kapasitas simpanan menyebabkan sel hati mengubahnya menjadi lemak $^{8}$.

Di dalam tubuh asupan protein berlebih dapat meningkatkan simpanannya dalam bentuk lemak. Hal tersebut disebabkan karena protein mengalami proses deaminase. Deaminase adalah proses terpisahnya gugus amino dari asam amino yang menyebabkan keluarnya nitrogen dari tubuh dan berubahnya ikatan karbon menjadi asetil ko $\mathrm{A}^{21}$. Selanjutnya asetil ko $\mathrm{A}$ mengalami proses lipogenesis sehingga berubah menjadi tligeserida ${ }^{8}$. Asupan zat gizi makro yang terakhir adalah lemak. Tubuh manusia memiliki kemampuan yang tidak terbatas untuk menyimpan lemak. Trigliserida merupakan senyawa lipida yang bersumber dari makanan ${ }^{8}$. Proses lipolisis menyebabkan trigliserida dipecah menjadi gliserol dan asam lemak. Melalui proses metabolisme gliserol dapat diubah menjadi glukosa atau piruvat, kemudian diubah menjadi asetil ko $A$ dan mengalami siklus TCA untuk pembentukan energi ${ }^{21}$. Namun jika sel tidak membutuhkan energi, maka asetil ko A diubah dalam bentuk lemak $^{8}$.

Berdasarkan hasil wawancara food recall siswa lebih banyak mengkonsumsi makanan yang mengandung tinggi karbohidrat, protein, dan lemak seperti nasi, mie, roti, susu, gorengan, dan minuman kemasan.

Hasil penelitian menunjukkan bahwa rata - rata total energy expenditure pada siswa status gizi obese lebih tinggi dibandingkan dengan siswa status gizi normal. Diketahui bahwa rata - rata total energy expenditure pada siswa status gizi obese dalah 2079,20 kkal dan siswa status gizi normal adalah 1684,84 kkal. Analisis statistik menunjukkan bahwa terdapat hubungan signifikan antara total energy expenditure dengan status gizi siswa $(p=0,000)$.

Tabel 2. Asupan Energi, Protein, Lemak, Karbohidrat, TEE berdasarkan Status Gizi Siswa SDN Pacarkembang 1 Surabaya

\begin{tabular}{|c|c|c|c|}
\hline \multirow[b]{2}{*}{ Variabel } & \multicolumn{2}{|c|}{ Status Gizi } & \multirow{2}{*}{$\begin{array}{l}\text { Total } \\
(n=66)\end{array}$} \\
\hline & $\begin{array}{l}\text { Normal } \\
(n=46)\end{array}$ & $\begin{array}{l}\text { Obese } \\
(n=20)\end{array}$ & \\
\hline $\begin{array}{l}\text { Energi } \\
\text { (kkal/hari) }\end{array}$ & $1600,13 \pm 300,92$ & $1917,64 \pm 356,23$ & $3517,77 \pm 657,15$ \\
\hline $\begin{array}{l}\text { Protein } \\
\text { (g/hari) }\end{array}$ & $61,60 \pm 18,97$ & $74,17 \pm 19,51$ & $135,77 \pm 38,48$ \\
\hline $\begin{array}{l}\text { Lemak } \\
\text { (g/hari) }\end{array}$ & $60,59 \pm 19,84$ & $72,13 \pm 25,13$ & $132,72 \pm 44,97$ \\
\hline $\begin{array}{l}\text { Karbohidrat } \\
\text { (g/hari) }\end{array}$ & $201,84 \pm 42,44$ & $243,73 \pm 51,46$ & $445,57 \pm 93,90$ \\
\hline $\begin{array}{l}\text { TEE } \\
\text { (kkal/hari) }\end{array}$ & $1684,84 \pm 201,54$ & $2079,20 \pm 250,20$ & $3764,04 \pm 451,74$ \\
\hline
\end{tabular}


Tabel 3.Tabulasi Silang Hubungan Asupan Energi, Protein, Lemak, Karbohidrat dan TEE dengan Status Gizi Siswa SDN Pacarkembang 1 Surabaya

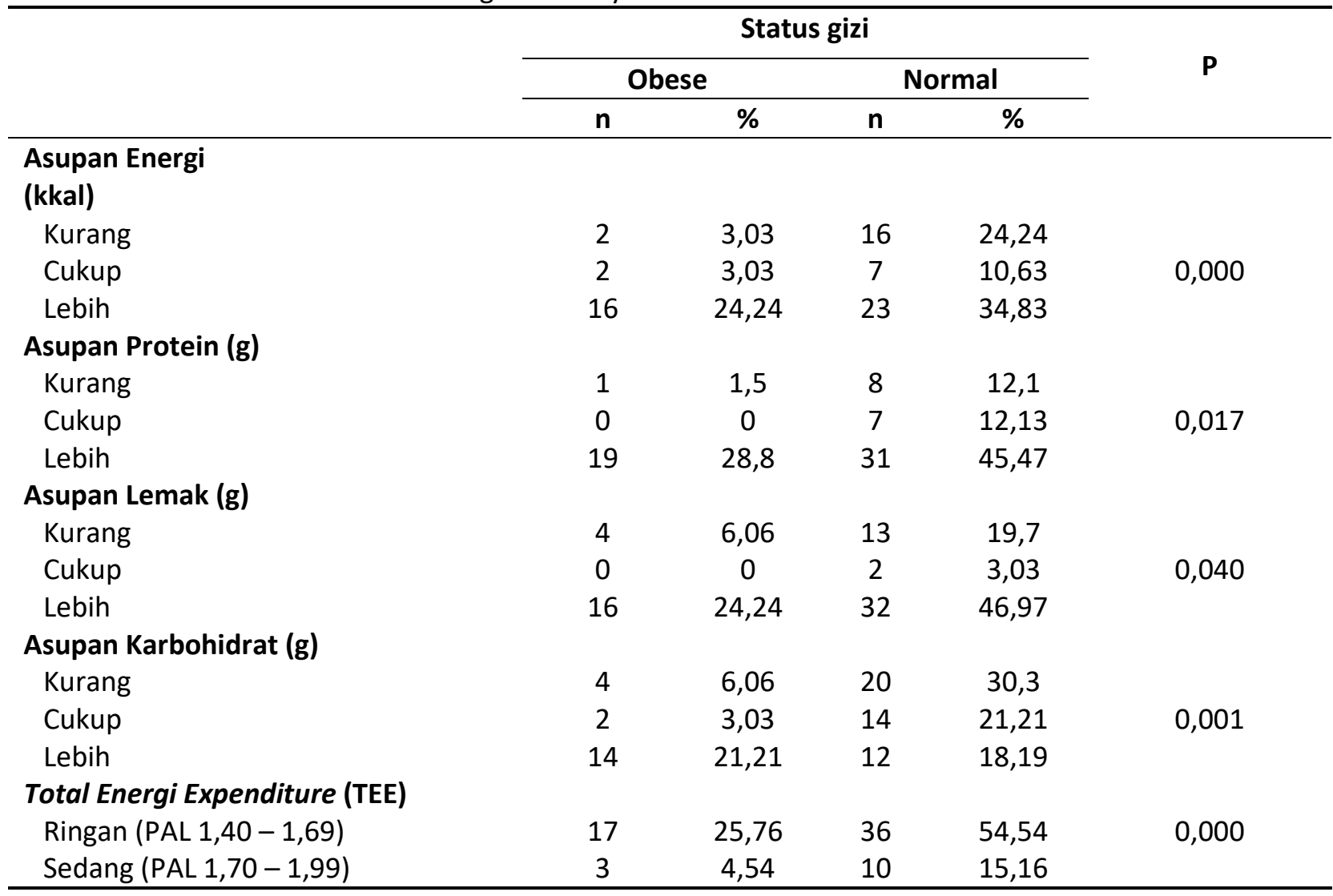

Status gizi memiliki pengaruh terhadap penggunaan energi di dalam tubuh baik untuk metabolisme basal maupun aktivitas fisik. Secara umum individu dengan status gizi kurang menggunakan energi untuk metabolisme basal lebih tinggi. Hal tersebut dilakukan sebagai upaya untuk mempertahankan berat badan. Sebaliknya pada individu dengan status gizi lebih cenderung menggunakan pengeluaran energi lebih besar untuk aktivitas fisik. Hal demikian berkaitan dengan lebih tingginya usaha yang digunakan oleh individu dengan status gizi lebih dibandingkan individu dengan status gizi kurang $^{21}$.

\section{KESIMPULAN}

Asupan energi dan zat gizi makro karbohidrat, protein, lemak dan total energy expenditure berhubungan dengan status gizi anak sekolah dasar. Sebaiknya anak sekolah dasar dapat mengurangi konsumi makanan tinggi energi, protein, lemak dan meningkatkan aktivitas fisik.

\section{ACKNOWLEDGEMENT}

Peneliti mengucapkan terima kasih kepada Kepala sekolah SDN Pacarkembang 1 Surabaya yang telah memberikan izin untuk dijadikan tempat penelitian sehingga penelitian ini dapat terlaksana serta adekadek siswa SDN Pacarkembang 1 kelas 4 dan kelas 5 yang telah meluangkan waktu membantu penelitian ini.

\section{REFERENSI}

1. Schlenker, E.D., R. S. Williams' Essentials of Nutrition and Diet Therapy. (Elsevier, 2011).

2. Rocha, C., Constante Jaime, P. \& Ferreira Rea, M. How Brazil's Political Commitment to Nutrition Took Shape. Global Nutrition Report - From promise to impact: ending malnutrition by 2030 (2016). doi:10.2499/9780896295841

3. Badan Penelitian dan Pengembangan Kesehatan. Riset Kesehatan Dasar (RISKESDAS) 2013. Lap. Nas. 2013 1-384 
(2013). doi:1 Desember 2013

4. Laksmiarti, T., Rachmawati, T. \& Juni Angkasawati, T. Riset Kesehatan Dasar 2013 Dalam Angka Provinsi Jawa Timur. (2013).

5. Peraturan Gubernur (PERGUB) No. 52 Tahun 2016. in (2016).

6. Octari, C., Liputo, N. I. \& Edison. Hubungan Status Sosial Ekonomi dan Gaya Hidup dengan Kejadian Obesitas pada Siswa SD Negeri 08 Alang Lawas Padang. J. Kesehat. Andalas 3, 131-135 (2014).

7. Hill J.O., Wyatt H.R., Peters, J. . Energy balance and obesity. NIH Public Access 126, 126-132 (2013).

8. Arisman. Gizi dalam daur kehidupan. (EGC Penerbit Buku Kedokteran, 2002).

9. Hill, J. O., Wyatt, H. R. \& Peters, J. C. Energy balance and obesity. Circulation 3, 126-132 (2012).

10. Vertikal, L. . Aktivitas fisik, asupan energi dan asupan lemak hubungannya dengan gizi lebih pada siswa SD Negeri Pondok Cina 1 Depok. (Universitas Indonesia, 2012).

11. Kharismawati, R., S. Hubungan Tingkat Asupan Energi, Protein, Lemak, Karbohidrat, Dan Serat Dengan Status Obesitas Pada Siswa Sd. 2-4 (2010).

12. Hutahean, G. D. . Hubungan pola makan dan aktivitas fisik terhadap kejadian obesitas anak kelas $v$ dan vi di sekolah dasar yayasan pendidikan shafiyyatul amaliyyah. (University of Sumatera Utara, 2013).
13. Rokhmah, F., Muniroh, L. \& Nindya, T. S. Hubunga tingkat kecukupan energi dan zat gizi makro dengan status gizi siswi SMA di Pondok Pesantren Al-Izzah Kota Batu. Media Gizi Indones. 11, 94-100 (2016).

14. Kurdanti, W., Suryani, I., Syamsiatun, M.H., Siwi, LP., Adityanti, M. . Faktorfaktor yang mempengaruhi kejadian obesitas pada remaja. J. Gizi Klin. Indones. 11, 179-190 (1925).

15. Huang, J.-Y. \& Qi, S.-J. Childhood obesity and food intake. World J. Pediatr. 11, 101-107 (2015).

16. Barasi, M. Nutrition at a Glance. (Blackwell Science Ltd, 2013).

17. Moehji, S. IImu gizi pengetahuan dasar ilmu gizi. (Papas Sinar Sinanti, 2002).

18. Sultana, S., Saleh, F. \& Ali, L. Childhood Obesity in Primary School Children of Middle and Upper-Middle Income Group in the Capital City of Bangladesh. Food Nutr. Sci. 6, 1185-1192 (2015).

19. Atika, W., Punuh, M. . \& Kapantov, N. . Hubungan Antara Asupan Energi Dan Zat Gizi Makro Dengan Status Gizi Pada Pelajar Di Smp Negeri 13 Kota Manado. Pharmacon 4, 303-308 (2015).

20. Sartika, R. A. . Faktor Risiko Obesitas pada Anak 5-15 Tahun di Indonesia. Makara, Kesehat. 15, 37-43 (2011).

21. Almatsier, S. Prinsip Dasar Ilmu Gizi. (Gramedia Pustaka Utama, 2001). 